\title{
TEOLOGI WIRAUSAHA
}

\begin{abstract}
Abodul Jaili ${ }^{*}$
Abstract: inthesoial theeryof religion, itiscommonlybdieved that theinmer aspet of man such as reigious experiencedbes havea rdein shapinghis atter, namdy extemal dimension How one bataves is a result of his her inner state Ones attitude is none other than the manifestation of his her religiousness On that basis, this paper argues that the spinit of entreprenearship that one has within him/ her is the result of his/ her faith-and also undestanding-of his her religion Thepeper hdds that it isrdigion that drives onetobean entreprener. TheIdamic word-viewconceming thedynamics of lifefor instance, has been the major sarce of inspiration for manyyoungsterstodbbusiness. This paper therforedeals with someIdamicteahingsconceminglifesuchas worldy well-bing freevill and thevalue of work beforeGod Thepeper hoverer also discovers that although Idamhas a lot to say coneming business, only few Musims made use of its teading do dadop what can be called Idamic entrepreneurship
\end{abstract}

Keywords: Islamicentreprenenship, worddy well-being freevill, Idamicvalue

\section{Pendahuluan}

Studi tentang kewirausahaan dapat didekati dengan berbagai disiplin ilmu, seperti sosiologi, antropologi, manajemen, politik, ideologi, dan lain-lain. Para ahli sosiologi, misalnya, mengkaji kewirausahaan sebagai sebuah fenomena sosial, model-model kewirausahaan, serta kepemimpinan yang ada dalam sebuah perusahaan, ahli antropologi mengetengahkan perlunya mengubah sikap-sikap tradisional dan menumbuhkan suatu etik/ etos kerja, para ahli politik menekankan perlunya kontrol dan dukungan politik, sedangkan para ahli manajemen membicarakan perlunya sistem manajerial yang tepat untuk menjamin keberlangsungan sebuah usaha.

Fenomena industrialisasi, yang kemudian di dalamnya muncul konsep kewirausahaan, bisa dikatakan merupakan "penyimpangan" dari pola kehidupan yang telah distrukturkan agama, sebab kebangkitan dunia industri dan proses industrialisasi berakar pada settingapa yang saat ini disebut kapitalisme: usaha massif memperoleh keuntungan material dengan menggunakan makanisme pasar.

Peristiwa tersebut, sebagaimana kata Ellen Meiksins Wood dalam The Origin of Capitalism tidak lahir di perkotaan Eropa melainkan dunia agraria Inggris. ${ }^{1}$ Industrialisasi

\footnotetext{
*Sekolah Tinggi Agama Islam Negeri (STAIN) Kudus.

${ }^{1}$ Peristiwa tersebut dipicu oleh ketika para pemilik tanah (landoards) melaksanakan endosurerevdution "revolusi pemagaran" , tanah-tanah milik mereka pada abad ke-16 sampai abad ke-18. Revolusi ini dimungkinkan karena disahkan parlemen.Tetapi pada saat yang sama juga karena- berbeda dengan Prancis-sebagian besar tanah terkonsolidasi dalam kepemilikan para landards Sebagai akibatnya, para petani secara massif kehilangan hak-hak tradisional memanfaatkan sumber daya agraria bagi penghidupan. Revolusi ini melahirkan perubahan total pola relasi sosial petani-pemilik tanah yang sebelumnya gabaeadscipti (terikat dengan tanah) menjadi propatyrdations D ari sinilah aktivitas masyarakat menjadi marke dependent, dalam arti akses atas tanah dan alat-alat produksi lainnya tak lagi diatur hukum-hukum tradisional. Kian besar tanah berada dalam lingkup rezim ekonomi, keuntungan atas akses terhadap tanah itu sendiri jatuh kepada mereka yang mampu berproduksi secara kompetitif dan, dengan meningkatkan produktivitas, kian mampu membayar sewa lebih tinggi. Fachry Ali, "Sejarah, Industri dan Islam," dalam Gatra E disi K husus, Beredar Senin, 160 ktober 2006.
} 
beranjak dari perubahan total sikap mental, orientasi kerja, dan struktur sosial-politik atas dasar marke imperative Maka, pada esensinya, dunia industri dan proses industrialisasi adalah pemberlakuan sistem kehidupan dan mental baru dengan "disiplin pasar" dalam mencari keuntungan. Akumulasi modal, dvisinof labor, diferensiasi struktural, gedung-gedung pabrik, alat-alat teknologi maju, sistem transportasi, serta komunikasi canggih hanya manifestasi kasat mata dari berkinerjanya sistem kehidupan industrial.

Unsur yang tidak kasat mata, atau roh dari industrialisasi, adalah kewirausahaan. Konsep wirausaha lahir sebagai garda depan dalam industri karena menyangkut inovasi dan produktivitas seorang pengusaha. Joseph Schumpeter (1934) dengan tegas menyatakan bahwa wirausahawan adalah seorang inovator yang mengimplementasikan perubahan-perubahan di dalam pasar melalui kombinasi-kombinasi baru. Kombinasi baru tersebut bisa dalam bentuk 1) memperkenalkan produk baru atau dengan kualitas baru, 2) memperkenalkan metoda produksi baru, 3) membuka pasar yang baru (newmarke), 4) Memperoleh sumber pasokan baru dari bahan atau komponen baru, atau 5) menjalankan organisasi baru pada suatu industri.

Tulisan ini hendak melihat masalah kewirausahaan dalam kaitannya dengan ideologi (Islam). Perspektif ini penting mengingat tindakan seseorang juga dipengaruhi oleh sistem ideologinya, sebagaimana keyakinan masyarakat fenomenologi yang mempercayai bahwa kesadaran teologis masyarakat akan mewarnai persepsi mereka tentang realitas sosial. ${ }^{2} \mathrm{Hal}$ ini karena secara psikis seseorang cenderung memasukkan segala sesuatu yang berasal dari luar dirinya seperti simbol-simbol yang mencerminkan dunia di sekitarnya, norma, budaya, kehidupan sosial, serta perilaku orang yang akrab dengannya ke dalam sistem gejala kejiwaannya. Proses internalisasi pengalaman ini kemudian memengaruhinya dengan cara tertentu ketika memahami, merasa, berpikir dan berbuat. ${ }^{3}$

Sistem dengan berbagai kerangka ideologis dapat diumpamakan sebagai permukaan cermin. Realitas yang ditangkap adalah apa yang dipantulkan oleh sebuah cermin, sementara pantulan itu sendiri tergantung pada permukaan cermin. Jika cerminnya cembung, realitas yang kecil bisa menjadi besar. Jika cerminnya cekung, maka realitas yang besar bisa menjadi kecil. D emikian pula jika cerminnya retak, maka realitas yang menyatu dan koheren akan tampak tercerai-berai. Karena itu, kerangka ideologis yang berbeda akan merefleksikan realitas yang berbeda pula. ${ }^{4} \mathrm{D}$ engan demikian, konsep kewirausahaan merupakan cermin dari sistem teologi masyarakat. Masing-masing masyarakat beragama berpeluang merumuskan sistem teologi kewirausahaan sesuai dengan karakteristik yang dimilikinya.

\section{Basis Nilai Kewirausahaan dalam Islam}

D alam Islam, tidak ditemukan kata yang secara eksplisit semakna dengan kewirausahaan, namun yang banyak ditemukan adalah kata yang menunjukkan arti bekerja, seperti al-'amal, al-kasb al-sa'y, al-nas\}r, al-h\}infah dan lain-lain. D eretan kata ini secara umum

${ }^{2}$ Moeljarto Tjokrowinoto, "Konsep Pembangunan Berkelanjutan," dalam ed. Samodra Wibawa, Penbangunan BekkdanjutanmKonsepdanKasus(Yogjakarta: Tiara Wacana, 1991), 1.

3Vinacke, thePsydhdgy of Thinking(Toronto: McG raw Hill Book Company Inc., 1992), 285.

"Jesse F D illard, "Accounting as a Critical Social Science," dalam Acounting Auditing andAcountabilityJaurnal, Vol. 4,1991. 
berarti berkerja, mencari rezeki, dan menjelajah (untuk bekerja). Sejarah Islam juga mencatat bahwa Muhammad, istrinya dan sebagian besar sahabatnya adalah para entreprenerr. Oleh karena itu, sebenarnya tidak mengada-ada jika dikatakan bahwa mental entreprenershipinheren dengan jiwa umat Islam itu sendiri. Secara implisit unsur-unsur yang ada dalam kewirausahaan ada dalam Islam. Unsur-unsur tersebut adalah:

1) Aktif

Karakter seorang muslim adalah aktif, pekerja keras, dan memiliki etos kerja tinggi. Suasana batin (inmerlife) seseorang dapat menimbulkan rangsangan dari dalam (innerdrive). E tos kerja sebagai adionkonkret seseorang dapat didivedari pandangan seseorang mengenai a) worddriewIslam tentang kehidupan yang menekankan kepada pencapaian kesejahteraan duniawi, b) kemerdekaan dalam berbuat dan berkehendak, dan c) nilai kerja itu sendiri.

Di level imer life, ada sebagian komunitas muslim yang berpikiran fatalistis yang mengatakan bahwa segala sesuatu telah ditentukan langsung oleh Tuhan. Penganut pendekatan pasiismerdijiusini, pada dasarnya, tidak begitu peduli dengan soal kerja keras, kemiskinan ataupun ketimpangan sosial lainnya. Ada atau tidaknya kemiskinan dan ketimpangan sosial bukanlah urusan manusia, tetapi sepenuhnya urusan Tuhan. Pandangan sosial seperti ini dapat ditemukan dalam tradisi teologi umat mana saja, termasuk di dalamnya umat Islam. Di kalangan Muslim, pandangan ini dicarikan pembenarannya, antara lain, dari al-Qur'an surah al-Zukhruf ayat $32^{5}$ dan surah al-Nah $\} l$ ayat $71^{6}$ yang dipahami secara secara terpotong.

Meskipun mengacu pada ayat suci, pandangan ini mengandung kelemahan yang mendasar karena dibangun dari pemahaman yang tidak utuh, sepotong-sepotong. Pandangan tersebut sekaligus mengandung pengingkaran yang sewenang-wenang terhadap idealisme al-Q ur'an agar manusia selalu aktif mengupayakan keadilan dalam kehidupan sosialnya. O rang-orang yang bertanggung jawab atas berkembangnya paham pasivismekeagamaan ini tidak pernah mau memahami struktur ayat-ayat dalam al-Q ur'an; mana bagian yang berbicara tentang das sein (realitas yang ada, selalu fakta) dan mana yang berbicara perihal das sollen (realitas ideal sebagi cita-cita). Bagian ayat kategori pertama berfungsi membeberkan realitas yang menjadi tantangan ikhtiar kekhalifatan manusia. Sementara, bagian ayat kategori kedua berfungsi untuk menegaskan tujuan ke mana seharusnya ikhtiar manusia itu ditambatkan. Pemahaman ajaran secara doktriner, seperti yang ditebarkan di kalangan umat selama ini, cenderung meletakkan semua ayat sebagai acuan tentang das sollen apa yang seharusnya ada.

Untuk merubah kehidupan, orang harus bekerja. Kerja dalam Islam tidak hanya diartikan sebagai upaya mencari nafkah, baik bagi dirinya, keluarga, kerabat maupun orang lain, tetapi lebih dari itu kerja dalam Islam berdimensi ibadah. Bahkan membuang duri dari jalan pun, yang dalam konteks duniawi dipahami sebagai upaya penyelamatan diri dan masyarakat dari kecelakaan, termasuk dalam kategori ibadah. D emikian pula, memberi minum kepada anjing yang kehausan, misalnya, dimaknai sebagai ibadah. Surah al-Tawbah ayat $105^{7}$ dan hadith nabi yang artinya "Nabi ditanya tentang pekerjaan yang

5al-Qur'an, al-Zuhnuf: 32.

6al-Q ur'an, al-Nahl: 71.

7al-Q ur'an, al-Tawbah 105. 
lebih utama. Kemudian Beliau bersabda: Jual beli yang dilakukan secarajujur dan pekerjaan hasil kerja kerasnya sendiri" menunjukkan bahwa Islam lebih menghargai, bahkan mengistimewakan, para pekerja keras.

2) Produktif

Secara teoretik, terdapat banyak pengertian tentang produktivitas, namun secara sederhana dapat dikelompokkan menjadi tiga bagian, yaitu: a) rumusan tradisional bagi keseluruhan produktivitas tidak lain adalah rasio dari apa yang dihasilkan (at put) terhadap keseluruhan peralatan produksi yang digunakan, b) produktivitas pada dasarnya adalah suatu sikap mental yang selalu mempunyai pandangan bahwa mutu kehidupan hari ini lebih baik dari hari kemarin dan hari esok lebih baik dari hari ini, c) produktivitas merupakan interaksi terpadu secara serasi dari tiga faktor esensial, yaitu investasi, manajemen dan tenaga kerja. ${ }^{8}$

Senyatanya, produktivitas bukan barang baru dalam Islam. Dalam surah al-Mulk ayat 2 Allah dengan tegas menyatakan bahwa kita diciptakan untuk berkompetisi dalam hal kebaikan. Itu artinya kita mesti produktif, sebab tanpanya kompetisi itu tidak ada. D alam sebuah Hadith, Rasul juga pernah menyatakan bahwa barang siapa yang hari ini sama seperti kemarin adalah rugi. Jika lebih jelek celaka. Jadi, pilihan satu-satunya hanyalah melakukan sesuatu yang lebih baik dan lebih bermakna. Produktivitas tersebut diperoleh dengan memberi kebebasan kepada umat untuk memilih profesi masing-masing. Ia dipersilahkan memilih sektor yang ia sukai. ${ }^{9} \mathrm{D}$ i samping itu, produktivitas ini tidak terkait dengan jenis kelamin. Peluang mereka sama, dan yang membedakan adalah prestasi dan produktivitas kerja, bukan sex (jenis kelamin bawaan). ${ }^{10}$

Oleh karena itulah tidak salah jika kemudian dalam konteks ini disimpulkan bahwa Islam sangat menjunjung tinggi profesionalisme. Banyak hadith yang berbicara tentang masalah ini, antara lain, yang artinya: "Barang siapa melimpahkan satu persoalan kaum muslimin kepada seseorang (yang tidak profesional), sedang di sana masih ada yang lebih profesional, maka ia telah mengkhianati Allah dan Rasulnya." ${ }^{11}$

Semua unsur yang dapat memotong prinsip ini, jauh-jauh hari Islam telah berusaha membasminya. Nepotisme, sektarianisme, dan kronisme adalah contoh unsur tadi. 'Umar Ibn Khat \}t\}a $>b$ pernah mengatakan bahwabarang siapa memberipekerjaan kepada seseorang hanya karena ia senang kepadanya, atau karena ia masih kerabat, sungguh ia telah berkhianat kepada Allah, rasul dan seluruh kaum mukminin.

3) Inovatif

Banyak definisi mengenai apa itu kreatif. Namun secara umum disebutkan bahwa karakteristik orang yang kreatif adalah selalu melihat segala sesuatu dengan cara berbeda dan baru, dan biasanya tidak dilihat oleh orang lain. O rang yang kreatif pada umumnya mengetahui permasalahan dengan sangat baik dan disiplin, dan dapat melakukannya

${ }^{8}$ Purwatiningsih, ManajemenSumberDaya Manusia(Semarang: Stikubank: 1992), 54.

'al-Q ur'an, al-Isra': 84.

${ }^{10}$ al-Q ur'an, al-Nisa': 32.

${ }^{11}$ Hadith riwayat al- $\mathrm{H}$ \{a>kim dani Ibn 'Abba>stergolong hadith d \}a'i >f. Meski hadith inid \} a'i $>$ f, iatetap bisa dijadikan hujjah karena diperkuat hadith "idha> wusida al-amr ila> ghayr ahlih, faal-tantaz\}ir al-sa>'ah." LihatAh\}mad ibn 'Abd

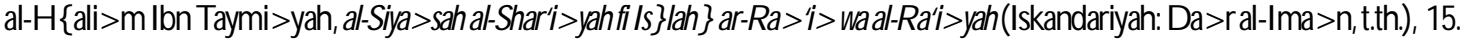


dengan cara menyimpang dari cara-cara tradisional. Proses kreativitas melibatkan adanya ide-ide baru, berguna, dan tidak terduga, tetapi dapat diimplementasikan, setelah melalui tahap exporing inverting dan doosing Cara berpikir dan bertindak inilah yang akhirnya menjadikan seseorang inovatif. D alam dunia ekonomi, inovasi dapat meliputi 5 hal, yakni: a) diperkenalkan produk baru yang sebelumnya tidak ada, b) diperkenalkan cara berproduksi baru, c) pembukaan daerah-daerah pasar baru, c) penemuan sumber-sumber bahan mentah baru, dan d) perubahan organisasi industri sehingga meningkatkan efisiensi industri.

D engan memahami makna kreatif inovatif di atas, maka dalam Islam ditemukan beberapa tura $>$ thyang mendorong ke arah tersebut, antara lain adalah dalam kasus membuka lahan baru (ih\}ya>' al-mava $>$ t). ${ }^{12}$ Umat Islam diminta untuk mencari lahan baru demi peningkatan produktivitas. Lahan baru ini bisa berupa tanah mati, yakni tanah yang tidak ada pemiliknya dan tidak dimanfaatkan oleh satu orang pun. Sedangkan yang dimaksud dengan menghidupkannya adalah memanfaatkan tanah itu baik dengan menanaminya maupun dengan mendirikan bangunan di atasnya ${ }^{13}$ berdasarkan hadith Rasulullah yang artinya: "Barangsiapa menghidupkan tanah yang telah mati, maka tanah tersebut untuknya." (HR. Ahmab ibn Hanbal dan Turmudhi) dan hadith yang artinya; "Barangsiapa menghidupkan tanah yang tidak dimiliki seseorang, maka ia lebih berhak atas tanah tersebut."(HR. Bukhari dan Abu Dawud)

Kedua hadith ini menunjukkan bahwa jika seseorang menggarap sebidang lahan kosong, belum dimiliki orang lain, kemudian menggarap lahan itu, mengairinya, menanam tumbuh-tumbuhan di atasnya dan memagarnya, maka lahan itu menjadi miliknya. Kedua hadith itu juga memotivasi umat Islam untuk menjadikan lahan kosong menjadi lahan produktif, sehingga karunia yang diturunkan Allah dapat dimanfaatkan semaksimal mungkin untuk kepentingan dan kemaslahatan umat manusia, sebagaimana hadith $\mathrm{Nabi}$ yang artinya: "Allah menyukai pekerja yang sangat baik ketika bekerja."14

\section{Menelusuri Teologi Wirausaha}

Secara harfiah teologi adalah ilmu tentang Tuhan. Teologi adalah disiplin ilmu yang

\footnotetext{
${ }^{12}$ D alam literatur fikih, para ulama berbeda pendapat dalam cara pengolahannya. Menurut ulama Hanafiyah dan Malikiyah adalah dengan cara menggarapnya sebagai lahan pertanian. Untuk itu, perlu dibersihkan pepohonan yang ada di dalamnya, mencangkul lahan untuk pertanian, membuat saluran irigasi baik dengan menggali sumur maupun dengan mencari sumber air lainnya, menanaminya dengan pepohonan atau tanaman yang menghasilkan serta memagarinya. Kemudian ulama Shafi'iyah menyatakan bahwa cara untuk mengolah lahan kosong yang tidak dimiliki seseorang dikembalikan pada adat istiadat yang berlaku di daerah itu. Jika lahan itu dimaksudkan untuk tempat tinggal, maka lahan itu perlu dipagar dan membangun rumah di atasnya. Jika dimaksudkan untuk pertanian, maka lahannya diolah, irigasinya dibuat, baik dengan menggali sumur maupun mengambil air dari sungai dan menanami lahan itu dengan tanaman produktif sesuai dengan keinginannya. Sedangkan menurut ulama Hanabilah bahwa ih\} ya>' al-mava>titu cukup dilakukan dengan memagar sekelilinglahan yang ingin digarap, baik untuk pertanian, tempat pengembalaan maupun untuk perumahan. Ini didasarkan atas hadis Nabi:

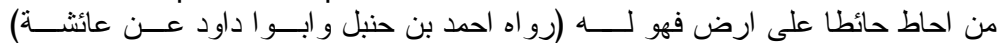
Akan tetapi ulama fikih lain menyatakan bahwaih\}ya >' al-mema>ttidak cukup hanya dengan memagar sebidang tanah tanpamenggarapnya LihatIma>m al-Kasa>ni>, Badb>i' 'd-Fana>idVVol.6(Beirut:Da>ralFikr, t.th.), 194; Ibn Quda>mah, al-Mughi>, Vol. 5 (Riyadh: Maktabatal-Riya>d\} al-H \{adi>thah,t.th.), 514.

${ }^{13}$ al-Nabha>ni >, MenbangunSistemEkonom, 74.

${ }^{14} \mathrm{MujamT}$ \{abra>ni>, Albahi>n:B1
} 
berkaitan dengan Tuhan ataupun dengan realitas ketuhanan (diving reality) khususnya hubungan dengan Tuhan dengan dunia (Gools rdation to the nordd). ${ }^{15}$ Thomas Aquinas mendefinisikannya secara spesifik, sebagai pikiran Allah, ajaran Allah dan memimpin kepada Allah. ${ }^{16}$ William L. Resse menyebutkan bahwa teologi adalah pemikiran tentang ketuhanan. William Ockham menyebut teologi sebagai disiplin ilmu yang membicarakan kebenaran wahyu serta independensi filsafat dan ilmu pengetahuan. ${ }^{17}$ Bisa juga didefinisikan sebagai keseluruhan pengetahuan adikodrati yang objektif lagi kritis dan yang disusun secara metodis sistematis dan koheren. Pengetahuan ini mengangkat hal-hal yang diimani sebagai wahyu Tuhan atau berkaitan dengan wahyu. ${ }^{18}$

Sebagai sebuah terminologi, teologi sebenarnya bukan berasal dari khazanah dan tradisi Islam, walaupun sering dipakai oleh cendekiawan muslim kontemporer. Kata teologi sebenarnya terambil dari khazanah tradisi kristiani. ${ }^{19}$ D alam Islam, istilah yang lazim digunakan adalah 'aci >dah yakni sesuatu yang berkenaan dengan keyakinan (iman) seorang mukmin. ${ }^{20}$

Dalam tulisan ini, kata teologi tidak penulis maksudkan sebagaimana uraian di atas. Penulis menggunakan kata teologi dalam pengertian yang luas dan cakupan yang komprehensif. Teologi dimaknai sebagai kumpulan ajaran mana saja yang disusun secara koheren menyangkut hakekat Tuhan dan hubungan-Nya dengan umat manusia serta alam semesta. ${ }^{21}$ Teologi adalah sebuah disiplin akademik yang merujuk pada ajaran ketuhanan dalam hubungannya dengan dunia dari proses penciptaan sampai penyempurnaan. Lebih

\footnotetext{
${ }^{15}$ M. D awam Rahardjo, Idamdan Transformas Budaya(Yogyakarta: D ana Bakti Prima Yasa, 2002), 19.

${ }^{16}$ Sinclair B. Ferguson, Thedogy (Illinois: D owners Grove, 1988), 680-681.

${ }^{17}$ Abdul Rozak, IlmiKalam(Bandung: Pustaka Setia, 2007), 14.

${ }^{18}$ Fr. Hartono, PengantarTedog (Yogyakarta: Kanisius, 1994), 33.

${ }^{19}$ Harun Nasution, IsamRasional (Bandung: Mizan, 1998), ix.

${ }^{20}$ Persinggungan dunia Islam dengan tradisi Yunani sering disebut sebagai awal dari perumusan 'aci>dahdalam Islam. Perumusan tersebut menggunakan logika yang dipakai oleh tradisi mereka. Perumusan tentang Tuhan, misalnya, metode umum yang dipakai oleh mutakallimin adalah isidla $>1$ K aum mutakallimin membedakan antara dali $>1$ (bukti dalam pengertian tanda) dan dala>lah(bukti dalam skema atau struktur). Jika seseorang melihat asap (smoke), asap di sini adalah tanda (proof) bahwa ada api. Jadi, api adalah madlu>l ('alayh), objek atau fakta yang ditunjukkan. Jika seseorang menyimpulkan (infer) madu>l dari dali >l, maka proses demikian ini disebut istida $>1$. Pekerjaan istida>ldapat dilakukan hanya jika ada koneksi (táalluq) antara dalil dan madlul. Ini tidak berarti bahwa tanda (sig) harus berkorespondensi dalam sifat dan esensinya dengan benda yang ditunjukkan. Ini dapat terjadi, misalnya, ketika kita melihat bagian dari tubuh badan dan menyimpulkan dari situ ada keseluruhan tubuh. Tetapi mungkin juga terjadi bahwa kita memulai dari suarayang kita dengar untuk mengetahui seseorang yang menghasilkan suara itu, karenaitulah dali>ldan nadu>lberbeda dalam esensinya. Dengan carayang sama, kitajuga dapat menyimpulkan eksistensi Tuhan berdasarkan kejadian yang terjadi di muka bumi, meskipun secara keseluruhan berbeda dari Tuhan dalam hal sifat dan esensinya. Format logika kalam yang mendasarkan pada indicativesignitulah yang oleh mutakallimin disebut sebagai isida $>$ lbialsha $>$ hid'ala $>$ d-ga $>$ ibatau qija $>$ sal-ga $>$ ib'ala $>$ d-Sha $>$ hid Sha $>$ hidberarti yang hadir (present), dunia yang tampak dan gha>ibberarti yang tersembunyi (hiddan), berada di wilayah inilah Tuhan dan sifatsifat-Nya. Tuhan telah menciptakan sesuatu yang hiddendan manifest. Sesuatu yang masfeetdapat dijadikan bukti (tanda) bagi yang tersembunyi. Manusia harus melakukan koneksi antara keduanya dengan cara isida >lmaupun qiya $>$ s Q iyas di sini tidak hanya analogi, tetapi istilah umum untuk setiap bentuk usaha intelektual dan spekulasi yang mengarah kepada hasil yang baru; kull ma $>$ 'uimabial-isida $>$ Innghayrbadhavala $>\mathrm{h}$ \}as\}s\}a(eeythingthesisknown byinferenewithautbingeident orpereivedbythesenses; segala sesuatu yang diketahui melalui inferensi tanpa menjadi nyata atau dapat dilihat oleh penglihatan). Lihat Josef van Ess, "The Logical Structure of Islamic Theology," dalam Issa J. Boullata (ed.), an Onthdogyof IdamicThedogy(Montreal, Q uebec, Canada: McGill Indonesia-IAIN D evelopmentProject, 1992), 127-130; Ja>mil Sulayba, Mujama-Falsadi> (Beirut: Da>ral-Kita>b, 1988), 92.

${ }^{21}$ Loren Bagus, KamusFilsafat(Jakarta: G ramedia, 2000), 1090.
} 
tegas lagi, teologi adalah pola beragama masyarakat atau kekhasan suatu kelompok agama dalam menjalankan ajarannya. ${ }^{22}$

Jika teologi tersebut dihubungkan dengan fakta umat Islam, maka ada sesuatu yang ganjil. D unia Islam praktis merupakan kawasan bumi yang relatif terbelakang di antara penganut agama-agama besar. Negeri-negeri Islam tertinggal oleh Eropa Utara, Amerika Utara, Australia, dan Selandia Baru yang Protestan; Eropa Selatan dan Amerika Selatan yang Katholik; Eropa Timur yang Katholik Ortodox; Israel yang Yahudi; India yang Hindu; Cina, Korea Selatan, Taiwan Hongkong, Singapura yang Budhis Konfusianis; Jepang yang Budhis Taois; Thailand yang Budhis. Praktis di semua penganut agama besar di muka bumi ini, para pemeluk Islam adalah yang cukup rendah dalam penguasaan sains dan teknologi. A pa masalahnya? D alam kaitannya dengan teologi, ternyata sistem teologi yang dianut mayoritas muslim tidak menjadikannya produktif jika berhadapan dengan modernisasi yang global. Paradigma modernisasi global yang mengusung teori developmentalisme ${ }^{23}$ disinyalir telah melahirkan persoalan-persoalan baru seperti sentralisasi kekuasaan, lemahnya posisi rakyat dalam tawar-menawar dengan pemerintah, melebarnya jurang kesenjangan sosial, ketimpangan ekonomi pusat-daerah, kota-desa, kaya-miskin, kaum terdidik-tak terdidik, dan lain-lain.

Bertolak dari keprihatinan tersebut, agama yang secara sosial juga menjadi faktor perubahan, kemudian, dipahami tidak sekadar pada dimensi das sein melainkan lebih pada dimensi das solen yakni dimensi empirik yang bisa dilihat dan dirasakan. Hasilnya, Ali Asghar Engineer menggagas teologi pembebasan, ${ }^{24}$ Harun Nasution mengemukakan idenya tentang teologi rasional, ${ }^{25}$ Nurcholis Madjid mengungkapkan gagasannya tentang "sekularisasi" dan "liberalisasi" pemikiran Islam ${ }^{26}$, A bdurrahman Wahid mengedepankan ide transformasi sosial umat Islam dalam konteks kehidupan berbangsa dan bermasyarakat melalui gerakan sosio-

\footnotetext{
${ }^{22}$ Stephen B Bevans, Modds of Contextual Theology(New York: O rbis Books, 1992), 39.

${ }^{23}$ Secara teoretik, teori developmentalisme adalah campuran antara pemikiran fungsionalisme struktural dengan pemikiran behaviorisme kultural Parsonian. Menurut teori ini, perkembangan masyarakat berubah secara linier, selaras, serasi dan seimbang dari unsur masyarakat paling kecil sampai pada perubahan total dari tradisisonal menuju modern. Semula developmentalisme adalah salah satu teori pembangunan, namun kemudian berkembang menjadi ideologi. Teori ini pada dasarnya merupakan kelanjutan program pemulihan ekonomi dunia ketiga. Motif utamanya adalah membendung pengaruh komunisme di negara dunia ketiga yang cenderung memilih bentuk lain sosialisme. Asumsinya, sumber penyebaran komunisme adalah kemiskinan. Karena itu, penangkal penyebaran komunisme adalah pembangunan ekonomi yang mampu menghapus kemiskinan. Sedangkan di dunia ketiga lahir nasionalisme ekonomi sebagai kelanjutan nasionalisme politik sesudah merdeka dari penjajahan. Bentuk nasionalisme yang paling lazim adalah industrialisasi. Kritik terhadap developmentalisme datang dari haluan kiri dan kanan. D ari sisi kiri, developmentalisme dikritik karena menguatkan ketergantungan dunia ketiga terhadap negara maju, karena perekonomian nasional semakin didominasi modal asing. Sedangkan dari sisi kanan, developmentalisme dinilai telah melahirkan pemerintahan otoriter, bahkan akhir-akhir ini melahirkan rezim anti kapitalis dan pro sosialis, seperti di Kuba, Venezuela, Ekuador, Bolivia, dan Argentina, sekalipun penyebaran komunisme telah berhenti. D engan kata lain, developmentalisme telah melahirkan musuh-musuh baru dalam konteks melawan neoliberalisme. Lihat Rajesh Chandra, IndustrializationandDevdopment intheThird World(New York: Chapman and Hall, 1992), 4; Tempo 18 Mei 2009.

${ }^{24} \mathrm{Ali}$ Asghar Engineer, Islamdan Penbdbasan(Yogjakarta: LKIS, 1993).

${ }^{25}$ Harun Nasution, IslamRasional, (Bandung: Mizan, 1998).

${ }^{26}$ Nurcholish Madjid, Isam DdktrindanPeradaban: Sebuah Tdaah KritistentangMasalah Kèmanan, Kemanusiaan dan Kemodeman(Jakarta: Paramadina, 1995).

${ }^{27}$ Abdurrahman Wahid, "Islam, Pluralisme dan D emokrasi," dalam Arief Afandi (ed.), Idam Demokrasi atas Bawah: Pdemik Strateej PejuanganUmatModa GusDurdanAmienRais(Y ogjakarta: Pustaka Pelajar, 1997).
} 
kultural. ${ }^{27}$

Masih dalam kerangka ideologi yang membumi ini, Dawam Rahardjo mencoba merefleksikan perubahan sosial ekonomi dan politik menuju terciptaya masyarakat yang adil dan demokratis dengan memadukan nilai-nilai Islam dan teori-teori pembangunan. ${ }^{28}$ Kuntowijoyo mengupayakan transformasi kemasyarakatan menuju cita-cita profetik, yaitu humanisasi, emansipasi dan transendensi. ${ }^{29}$

Mansour Fakih menggagas teologi kritis (kaum tertindas) sebagai bentuk kontra diskursus terhadap wacana developmentalisme yang telah menjadi mainstream ${ }^{30}$ Masdar Farid mencoba membangun paradigma ekonomi yang berkeadilan dengan gagasan teologi populis. ${ }^{31}$ Sementara itu, Moeslim Adurrahman berupaya membangun teologi transformatif yang lebih menekankan pada hubungan dialektikal antara teks dan konteks dengan tidak memaksakan realitas pada idealitas teks. ${ }^{32}$

Melihat beberapa ikhtiar pemikir-pemikir di atas, penulis mencoba menimbangnya dari sisi terapan, sebagaimana digagas oleh Muslim Kadir. ${ }^{33}$ Menurut cara pandang Islam terapan, untuk menyatakan bahwa ada yang salah dalam Islam jelas tidak mungkin. Sebab dengan tegas Allah swt. menyatakan bahwa wahyu yang diturunkan kepada Nabi Muhammad adalah sudah sempurna. Proposisi kesempurnaan Islam tersebut, jika dipandang sebagai ungkapan doctrinal-teologis, maka tidak ada masalah. Sebab yang berbicara dalam konteks tersebut adalah nalar iman. Akan tetapi jika proposisi tersebut diposisikan sebagai proposisi empiris, maka banyak hal yang harus dijernihkan.

Dalam sejarah, Islam pernah tampil dengan tatanan yang mampu mengantarkan manusia pada kemajuan peradaban. ${ }^{34}$ Kesaksian ini tidak hanya diberikan oleh sejarawan Timur, seperti Ibn K haldu>n, ${ }^{35}$ al-Mas'u >di >, ${ }^{36}$ dan al-T \{abari > semata, melainkan juga oleh sejarawan Barat, seperti Philip K. Hitti, ${ }^{37}$ G runebaum, ${ }^{38}$ atau lainnya. Namun, sejarah juga mencatat kegagalannya. Fenomena perebutan kekuasaan, perang saudara, rendahnya produktivitas dan sejenisnya merupakan sederetan contoh betapa Islam gagal membangun peradaban yang kondusif. ${ }^{39}$

${ }^{28}$ M. D awam Raharjo, Idamdan Transformas Sosial-Ekonomi (Jakarta: Lembaga Studi A gama dan Filsafat (LSAF), 1999).

${ }^{29}$ Kuntowijoyo, ParadigmaIdam Interpreasi untuk Aksi (Bandung: Mizan, 1999).

${ }^{30}$ Mansour Fakih, Masjarakat Sipil untuk Tranformasi Sosial: PergdakanIdedọ LSMIndonesia (Yogjakarta: Pustaka Pelajar, 1996).

${ }^{31}$ Masdar Farid Mas'udi, Agama Keadlan, RisalahZakat: Pajak dalamIslam(Jakarta: Pustaka Firdaus, 1991).

${ }^{32}$ Moeslim Abdurahman, IdamTransomatif(Jakarta: Pustaka Firdaus, 1995).

${ }^{33}$ Muslim K adir, IlmuIdamTerapan(Yogjakarta: Pustaka Pelajar, 2003).

${ }^{34}$ Keberhasilan ini dikemukakan dengan rumusan bahwa bangkitnya Islam, barangkali, satu peristiwa paling menakjubkan dalam sejarah manusia. D alam tempo seabad saja, dari gurun tandus dan suku bangsa terbelakang, Islam telah tersebar hampir menggenangi separoh dunia. Menghancurkan kerajaan-kerajaan besar memusnahkan beberapa agama besar yang telah dianut berbilang abad. Mengadakan revolusi berpikir dalam jiwa bangsa-bangsa, dan sekaligus membina satu dunia baru: dunia Islam. Lihat L. Stoddard, Dunia Banu Idam terj. Muljadi Djojomartono (Jakarta: Panitia Penerbit, 1966), 11.

${ }^{35}$ Abd al-Rah \}ma>nibn K haldu >n, Ta>rikhIlonKhald $\gg$ n(Beirut:D a $>$ ral-Fikr, 1981), i-ii.

${ }^{36} \mathrm{Abu}>\mathrm{al}-\mathrm{H}$ \{asan'Ali>al-Mas'u>di>, Mun>jal-DhahabvaMa'a>dnal-Javhar(Beirut: Da>ral-Fikr, t.th.), i-iii.

${ }^{37}$ Philip K. Hitti, Histary of theArabs(London: the Macmillan Press, 1970).

${ }^{38}$ G.E. von G raunbaum, Isam EssaysintheNatureandGrouthof aCultural Tradition(London: Routlerge \& Kegan Paul Ltd., 1961).

${ }^{39}$ Lothrop Stoddard, theNewWodd of Idam(Chicago: the University of Chicago Press, 1950), 6. 
Menyamakan kegagalan muslim dengan kegagalan Islam memang tidak sepenuhnya bisa diterima. Sebab, sebagai wahyu, Islam tidak mungkin salah karena ia datang dari dzat yang serba maha. Lebih susah lagi, antara Islam dan muslim sudah menyatu, keduanya telah berubah menjadi sebuah sistem yang miltifaces ${ }^{40}$ dan bercampur aduk antara urusan ketuhanan yang sakral dengan 'kepentingan' kemanusiaan yang profan. D engan meminjam istilah W.C. Smith, maka ada koneksi Islam sebagai "keyakinan" dan "tradisi" yang tali-temali sehingga sulit dicari garis batasnya. ${ }^{41}$ Karena itulah, pertanyaan yang mutlak untuk dilihat dalam konteks ini adalah apakah kesalahan ini ada pada norma atau perilaku pemeluknya. ${ }^{42}$ Antara Islam sebagai ajaran dan perilaku pemeluknya adalah dua hal yang berbeda, meskipun tidak boleh dipisahkan karena Islam merupakan kesatuan antara ide dengan fakta, baik dalam perilaku perorangan ${ }^{43}$ maupun kehidupan bermasyarakat. ${ }^{44}$

D engan cara berpikir ini, cara paling terukur untuk menyatakan Islam berhasil atau gagal adalah dengan menilai ummatnya. Meminjam teori pantulan cerminnya Dillard, antara muslim dengan Islam dapat diumpamakan sebagai permukaan cermin. Realitas yang ditangkap adalah apa yang dipantulkan oleh sebuah cermin, sementara pantulan itu sendiri tergantung pada permukaan cermin. Jika cerminnya cembung, realitas yang kecil bisa menjadi besar. Jika cerminnya cekung, maka realitas yang besar bisa menjadi kecil. D emikian pula jika cerminnya retak, maka realitas yang menyatu dan koheren akan tampak tercerai-berai. ${ }^{45}$ Kegagalan tersebut secara umum ada pada dua sisi, yakni level abstrak dan konkret;; ${ }^{46}$ pada level inmard experience yakni persoalan basis nilai, persoalan batiniyah dan atuard behavior yang merupakan transformasi eksternal Islam. ${ }^{47}$

Persoalan akidah memang bisa dimaknai sebagai sebagai ilmu kalam yang bercorak filsafat. D engan pemaknaan ini, objek kajiannya adalah Tuhan. ${ }^{48}$ Tentu, perumusan tersebut saat itu sudah benar dan sesuai dengan masalah yang dihadapi oleh mutakallimin. ${ }^{49}$ Akan tetapi, dengan konteks yang ada sekarang, paradigma teologisnya tentu perlu dikaji ulang. Bukan soal salah benar sebuah ajaran teologi, akan tetapi soal produktif dan tidaknya teologi tersebut. Yang diperlukan bukan bagaimana filosofi tuhan, tetapi bagaimana sistem teologi

${ }^{40}$ M. Amin Abdullah, "Pengantar," dalam Metoddøg Studi Isam Ahmad Norma Permata et al. (Yogjakarta: Pustaka pelajar, 2000), 1.

${ }^{41}$ Nur K holish Majid, "Islam, Iman dan Ihsan sebagai Trilogi Ajaran Ilahi," dalam Kontdkstualisas DdktrinIsam dalamSgarah, ed. Budhy Munawar Rahman (Jakarta: Paramadina, 1994).

${ }^{42}$ Muslim A. K adir, IlmuIdamTerapan(Yogjakarta: Pustaka Pelajar, 2003), 119.

${ }^{43}$ D alam rumusan Ima $>m$ al-Ash'ari $>$ yang dikemukakan oleh al-Shahrasta $>$ ni $>$ di atasini tidak secara eksplisit disebut perilaku perorangan, akan tetapi rumusan unsur iman dalam bentuk perbuatan anggota badan tentu juga menunjuk unsur ini.

${ }^{44}$ Teori kehidupan kelompok sebagai bagian integral keberagamaan cukup terkenal dalam tulisan sarjana Barat. Terminologi yang dipakai adalah pengalaman keagamaan. Lihat Joachim Wach, theComparativeStudyof Reigions (New York: Columbia University Press, 1925), 27-60.

${ }^{45}$ Jesse F. D illard, "Accounting as a Critical Social Science," dalam Accounting Auditing andAccountabilityJarmal, Vol. 4, 1991.

${ }^{46} \mathrm{M}$. Amin Abdullah, Studi Agama, 23.

${ }^{47}$ Charles J. A dams, "Islamic Religious Tradition," dalam ed. Leonard Rindei, theStudyof MiddleEast(New York: John Wiley \& Sons, 1976), 32.

${ }^{48}$ Abu $>$ Mans\}u>ral-Ma>turidi>,Kta> batTavi>d(Beinut:Da>ral-Mashniq, 1970), 19.

${ }^{49}$ Sejarah memberi kesaksian bahwa problem utama yang harus dihadapi oleh umat setelah proses interaksi dengan orang pribumi di Persi, Romawi dan Mesir adalah keunggulan pribumi dalam kebudayaan Yunani. Lihat Ah\}madAmi>n,D \{uh\}a>d-ISa>m(Kairo: Maktabatal-Nahd\}ahal-Mis\}ri>yah,1952),40. 
itu memiliki poweryang praktis sehingga mampu berkontribusi terhadap etrepreneurhip Agar memiliki power, maka teologi yang merupakan imerlifeentreprener harus berintegrasi dengan "diri" secara utuh, bai aspek kognitif, eksistensial, maupun aspek relasional.

Dalam aspek kognitif, teologi tersebut berfungsi melepaskan pola pikir kategorikal yang telah terbentuk sebelumnya dan akhirnya memiliki kecerdasan spiritual (spinitual quation), sebagai penyempurna 8 kecerdasan majemuk (miltipleintelegences) pengusaha. ${ }^{50} \mathrm{D}$ alam aspek eksistensial, pengusaha harus belajar untuk "mematikan" karakter melalui proses pencarian jati diri (true sdf). Sedangkan dalam aspek relasional, teologi tersebut menjadikan dirinya merasa bersatu dengan kekuatan transenden, merasa damai, dilindungi, dan dituntun ke arah yang benar.

\section{Penutup}

Teologi merupakan kumpulan ajaran yang disusun secara koheren menyangkut hakekat Tuhan dan hubungan-Nya dengan umat manusia serta alam semesta. Teologi adalah sebuah disiplin akademik yang merujuk pada ajaran ketuhanan dalam hubungannya dengan dunia dari proses penciptaan sampai penyempurnaan. Lebih tegas lagi, teologi adalah pola beragama masyarakat atau kekhasan suatu kelompok agama dalam menjalankan ajarannya.

D alam konteks wirausaha, teologi Islam secara empiris mampu menjadikan umatnya

\footnotetext{
50Teori miltipleintdegenes dikembangkan oleh Howard Gardner pada tahun 1983 di Harvard University. Ia mensinyalir kecerdasan tradisional yang sering disebut IQ (Intdeegne Quation) terlampau terbatas, sehingga mengajukan konsep kecerdasan yang lebih luas, yakni: 1) kecerdasan linguistik, yakni kemampuan untuk berpikir dalam kata-kata dan menggunakan bahasa untuk mengutarakan makna yang pelik. Kecerdasan ini juga dibutuhkan dan nampak dalam diri entrepreneur saat ia harus menyusun sebuah businessplandan meyakinkan para pelanggan, 2) kecerdasan interpersonal, yakni kemampuan untuk memahami dan berinteraksi secara efektif dengan perspektif yang majemuk. Kecerdasan interpersonal memungkinkan kita berkomunikasi secara verbal dan nonverbal secara tepat. E ntrepreneur membutuhkan kecerdasan seperti ini untuk bergaul dengan sesama entrepreneur, investor; rekanan, dan sebagainya, sehingga ide-ide cerdas dapat dikomunikasikan, dimengerti, dan dilaksanakan secara baik, 3) kecerdasan intrapersonal, yakni kapasitas untuk memahami diri sendiri, apa dan bagaimana kemampuannya dalam bisnis. Kemampuan ini sangat urgen bagi pengusaha karena akan menaungi kecerdasan yang lain, 4) kecerdasan kinestetik, yakni kemampuan untuk memanipulasi benda dan menggunakan sejumlah ketrampilan fisik. Kecerdasan ini juga melibatkan kepekaan penentuan waktu dan kesempurnaan keterampilan antara kesatuan tubuh dan pikiran. Para penemu dan orang-orang yang memberikan produk atau jasa mekanis memerlukan kecerdasan tersebut. Untuk menciptakan produk atau jasa baru untuk konsumen, seorang entrepreneur memerlukan kecerdasan ini, 5) kecerdasan matematis-logis, yakni kecerdasan matematis-logis ialah kemampuan untuk menghitung, menjumlah dan berpikir secara masuk akal. Kecerdasan ini biasanya sangat kentara dalam pakar matematika, pegiat teknologi, dan programer komputer dan biasa dihubungkan dengan kecerdasan dalam pengertian tradisional (IQ ). Kecerdasan ini penting bagi entrepreneur karena ia setidaknya juga harus memiliki kemampuan dalam menghitung keadaan keuangan bisnisnya, menentukan langkah apa yang harus diambil untuk meningkatkan laba, menghitung ROI, IPO dan sebagainya, 6) kecerdasan naturalis untuk mengatur kemampuan manusia untuk membedakan makhluk hidup dan kepekaan terhadap fitur-fitur lain dari dunia nyata. Entrepreneur yang baik menggunakan kecerdasan naturalis untuk membedakan kebutuhan pelanggannya dan memilih produk/ jasa yang paling sesuai dan menguntungkan dalam sebuah pasar tertentu, 7) kecerdasan musikal untuk mengenali nada dan irama. Dalam konteks bisnis, kecerdasan ini memungkinkan pengusaha untuk berkreasi, menciptakan produk baru dan mereproduksi produk lama, dan 8) kecerdasan spasial yang diproyeksikan untuk berpikir dalam 3 dimensi. Kemampuan utama dalam kecerdasan spasial ialah imajinasi mental, penalaran spasial, grafis dan ketrampilan seni serta imajinasi aktif. Para pelaut, pilot, pemahat, pelukis dan arsitek memiliki tingkat kecerdasan spasial yang menonjol. Ini juga penting bagi entrepreneur dalam merancang tempat usaha yang ideal, kemasan produk yang memikat, dan sebagainya. Lihat Howard Gardner, Framesof Mind: theTheryof MultipleInteligenes(New York: Basic Books, 1983), 41-43.
} 
kreatif apabila secara internal bercorak integratif. Berbagai elemen keberagamaan (teologi, intelektual, pengalaman dan ritual) tidak berdiri sendiri, melainkan berada dalam barisan formasi teologis, yakni tatanan rancang bangun unsur-unsur pembentuk teologi, mulai dari aspek kognisi, internalisasi sampai objektivikasinya dalam lingkungan bisnis.

Hasil fermentasi unsur-unsur formasi teologis ini akan melahirkan spirit wirausaha, sehingga secara eksternal ia akan bertransformasi secara intrapersonal, interpersonal, dan transpersonal. Besaran spirit wirausaha seseorang bergantung pada kadar senyawa dan valensi unsur-unsur teologi yang dilakukannya.

\section{Daftar Rujukan:}

Abdurahman, Moeslim. Idam Transfomatif. Jakarta: Pustaka Firdaus, 1995.

Adams, Charles J. "Islamic Religious Tradition," dalam Leonard Rindei (ed.), the Study of MiddeEast. New York: John Wiley \& Sons, 1976.

Ali, Fachry. "Sejarah, Industri dan Islam," dalam Gatra, Edisi Khusus, Beredar Senin, 16 Oktober 2006.

Ami $>$ n,Ah\}mad. D $\{$ uh\}a $>$ a-ISa>mKairo:Maktabatal-Nahd\}ah al-Mis\}ni>yah, 1952.

Bevans, Stephen B. Modds of Contextual Thedogy. New York: O rbis Books, 1992.

Chandra, Rajesh. Industrialization and Dexdqpmett in the Third Wodd New York: Chapman and Hall, 1992.

Dillard, Jesse F. "Accounting as a Critical Social Science," dalam Acaunting Auditing and Acauntability Jaumal, Vol. 4, 1991.

Engineer, Ali Asghar. Idam dan Perbebasan Yogjakarta: LKIS, 1993.

Ess, Josef van. "the Logical Structure of Islamic Theology," dalam Issa J. Boullata (ed.), an Onthology of Islamic Thedogy. Montreal, Q uebec, Canada: McGill Indonesia-IAIN D evelopment Project, 1992.

Fakih, Mansour. Masjarakat Sipil untuk Transfomasi Sosial: Pergdakan Idkelog் LSM Indonesia. Yogjakarta: Pustaka Pelajar, 1996.

Ferguson, Sinclair B. Thedogy. Illinois: D owners Grove, 1988.

Gardner, Howard. Frames of Mind theThery of MultipleIntelligenes New York: Basic Books, 1983.

G raunbaum, G.E. von. Islam Essays in theNatureandGrouth of a Cultural Tradtion London: Routlerge \& Kegan Paul Ltd., 1961.

Kadir, Muslim. Ilmu Isam Terapan Yogjakarta: Pustaka Pelajar, 2003.

Kasa>ni > (al), Ima>m. Badb>'i d-Fana>'id Vol. 6. Beirut:D a >ral-Fikr, t.th.

Kuntowijoyo. Paradgma Idam Interprasi untuk Aks. Bandung: Mizan, 1999.

Madjid, Nurcholish. Isam Ddktrin dan Peradaban: SearahTdaahKritis tertangMasalah Keimanan,

Kemanusiaan dan Kemodkman Jakarta: Paramadina, 1995.

Mas'udi, Masdar Farid. Agama Keadlan, Risalah Zakat: Pajak dalam Isam Jakarta: Pustaka Firdaus, 1991.

Nasution, Harun. Isam Rasional. Bandung: Mizan, 1998.

Purwatiningsih. Manajemen Sumber Daya Manusia. Semarang: Stikubank, 1992.

Q uda>mah, Ibn. al-Mugri>, Vol. 5. Riyadl: Maktabat al-Riya>d\} al-H \{adi>thah, t.th.

Rahardjo, M. D awam. Idam dan Transfomasi Budaya Yogyakarta: D ana Bakti Prima Yasa, 
2002.

- - - - . Islamdan Transfomasi Sosial-Ekanomi Jakarta: Lembaga Studi Agama dan Filsafat (LSAF), 1999.

Sulayba>, Ja>mil. Mufjamal-Falsail >. Beirut:D a $>$ ral-Kita>b, 1988.

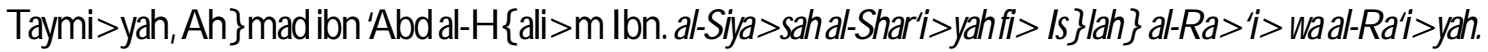
Iskandariyah: $\mathrm{D}$ a $>$ ral-Ima $>\mathrm{n}$, t.th.

Tjokrowinoto, Moeljarto. "Konsep Pembangunan Berkelanjutan," dalam Samodra Wibawa (ed.), Penbangunan Bekkdanjutanm Konsep dan Kasus Yogjakarta: Tiara Wacana, 1991. Vinacke. thePsychdgy of Thinking Toronto: McG raw Hill Book Company Inc., 1992.

Wach, Joachim. the Comparative Study of Reigions New York: Columbia University Press, 1925.

Wahid, Abdurrahman. "Islam, Pluralisme dan D emokrasi," dalam Arief Afandi (ed.), Isam Demmkras atas Bawahr Pdemik Stratege Pejuangan Umat Modd Gus Dur dan Amien Rais Yogjakarta: Pustaka Pelajar, 1997. 